Bangladesh J. Bot. 39(2): 161-168, 2010 (December)

\title{
MARINE ALGAE OF ST MARTIN'S ISLAND, BANGLADESH. XI. RED ALGAE (RHODOPHYCEAE)
}

\author{
Abdul Aziz and Mo Towhidur Rahman \\ Department of Botany, University of Dhaka, Dhaka 1000, Bangladesh
}

Key words: Seaweeds, Rhodophyceae, St. Martin's Island, Bangladesh

\begin{abstract}
Falkenbergia hillebrandii (Bornet) Falkenberg, Gelidiella tenera (J. Ag.) Schmitz, Halymenia floridana J. Ag., Liagora harveyiana Zeh and Polysiphonia harveyi Bailey of Rhodophyceae have been recorded and described for the first time from the St Martin’s Island, Cox’s Bazar, Bangladesh.
\end{abstract}

\section{Introduction}

A total of 200 marine algal taxa (seaweeds) have been reported so far, from Bangladesh (Ahmed et al. 2008, 2009, Aziz and Islam 2009, Aziz et al. 2010, Islam et al. 2010) of which 98 taxa under 53 genera are reds. The present work is an attempt to study the taxonomy of some preserved marine algae collected from the St Martin’s Island, Cox’s Bazar.

\section{Materials and Methods}

Marine algae collected on 06 January 1986 by Professor Sayed Hadiuzzaman and Professor Abdul Aziz, Department of Botany, University of Dhaka on 01 March, 1995 from the St. Martin's

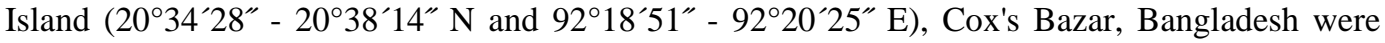
considered. The materials were preserved in marine water with $4 \%$ formalin, some were made into herbaria and have been stored in the first author's algal herbarium, Department of Botany, University of Dhaka.

\section{Results and Discussion}

In the present investigation a total of 5 taxa of Rhodophyceae have been worked out, illustrated and discussed.

\section{Order: Nemaliales, Family: Nemaliaceae}

\section{Liagora harveyiana Zeh}

(Figs 1A-D)

(Womersley 1965, Pl. 7, Fig. 1)

Habit: Plants very bushy, dichotomously branched, calcified.

Vegetative structure: Thalli strongly calcified, becoming rigid, usually $3-7 \mathrm{~cm}$ high with one to several main branches arising from a discoid holdfast, dichotomously branched after every 2 - 4 (-8) mm distance, forming a very dense rounded tuft; lower part of the thallus about $1 \mathrm{~mm}$ thick, branches narrowing gradually to about $0.5 \mathrm{~mm}$ below apices. Color pinkish-red with whitish crust (especially on lower parts). Basal cells of assimilatory filament cylindrical, 50.8 - $63.5 \mu \mathrm{m}$ long and 10.00 - $11.50 \mu \mathrm{m}$ broad; cells next to the basal cell cylindrical to slightly inflated in the middle, while distal cells are more inflated appearing ellipsoidal to balloon-like highly granulated; assimilatory cells with one pyrenoid in each; branching of as similatory filaments dichotomous proximally but trichotomous distally giving as bushy appearance. Terminal cells up to $10.16 \mu \mathrm{m}$ long, $6.35 \mu \mathrm{m}$ broad and may develop short or long flask shaped structure. Some tip cells cut off very small spherical structures appearing spermatangia. 
Reproductive structure: Plants dioecious. Spermatangia produced at apex of egg shaped assimilatory filaments up to a maximum of $3 \mu \mathrm{m}$ long and $2 \mu \mathrm{m}$ broad, stalked. Carpogonial branch 4 - 6 celled, develops laterally on a cell in the median portion of assimilatory filament; basal cell of the carpogonial branch usually large and hemispherical followed by gradually smaller cells in series bearing cylindrical carpogonium proper with trichogyne at the apex. Cystocarps hemispherical, $130 \mu \mathrm{m}$ long and $450 \mu \mathrm{m}$ broad.
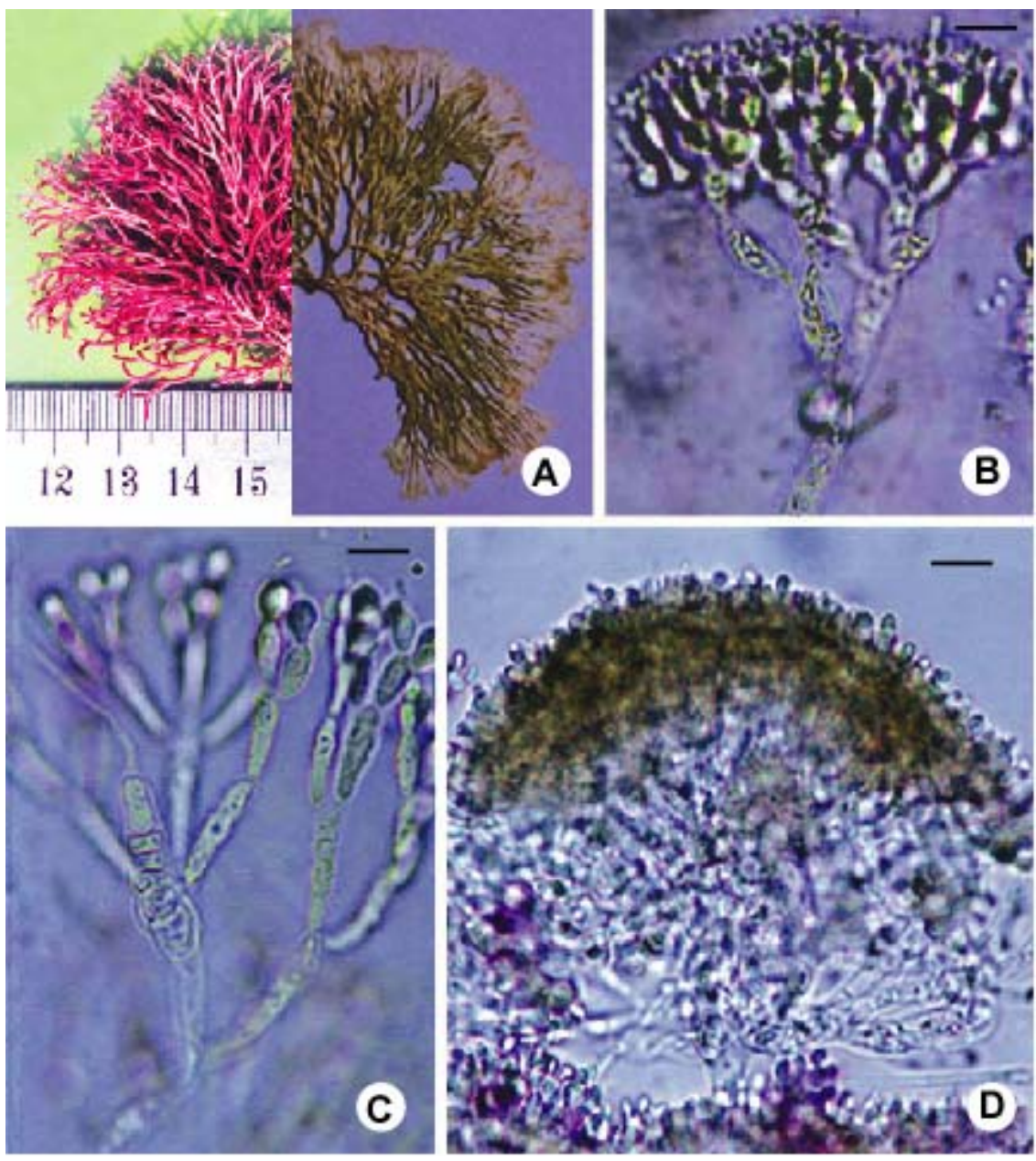

Figs 1A-D. Liagora harveyiana: A. A living (left) and herbarium (right) parts of the thallus. B. Assimilatory filament of a male plant showing spermatangia from peripheral cells. C. Assimilatory filament of a female plant showing carpogonial branch (note the cylindrical carpogonium). D. A hemispherical cystocarp. Bars: A, in cm; B-D $=30 \mu \mathrm{m}$.

Discussion: Islam (1976) reported L. ceranoids Lamx. and mentioned the probable presence of five or six spp. in the St. Martin's Island. The present species is an addition to the list of the taxa.

Habitat and local distribution: Grows on boulders, in the west coast of St Martin's Island at intertidal zone; collection no. 255, 01 March, 1995; very common. 


\section{Order: Gelidiales, Family: Gelidiaceae}

\section{Gelidiella tenera (J. Ag.) Schmitz}

(Figs 2A-E)

(Nora 1972, 277, Pl. 15, Fig. 64)

Habit: Thalli dichotomously branched, erect.

Vegetative structure: Plants erect, up to $10 \mathrm{~cm}$ tall, cartilaginous; the base producing short thick haptera-like attachment organ. Stipe broadly rounded in cross section, dichotomously branched distally. Branches elliptical in cross section basally but as they grow upwardly, flanges develop on both sides with midrib which diminishes near the apex, apices gradually narrowed into a filiform tip. Stipe $2 \mathrm{~mm}$ thick; branches up to $0.44 \mathrm{~mm}$ thick and $2.75 \mathrm{~mm}$ broad in the median region. Epidermal cells rectangular in surface view, varying sizes; cortical cells moderately thick walled, nearly rectangular but heavily thick wavy walled, compactly arranged in a bundle without intercellular spaces, cells in flanges elongated. Cells of conducting tissue are in the axial region, dorsiventrally flattened much smaller than cortical cells and narrowed lumen with dense cytoplasm forming midrib, $0.36 \mathrm{~mm}$ broad and $77.6 \mu \mathrm{m}$ thick. Only epidermal cells were found to contain several nearly spherical plastids. Reproductive structures not observed.
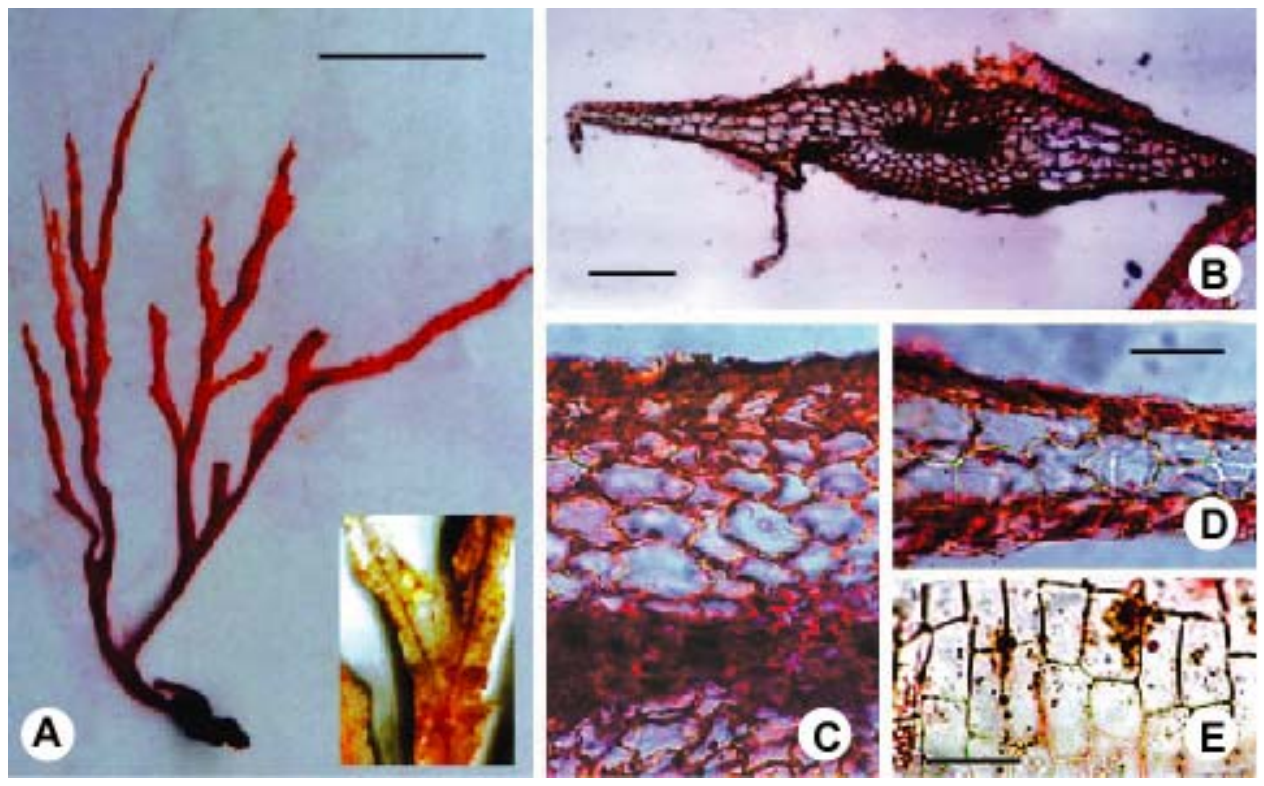

Figs 2A-E. Gelidiella tenera: A. A preserved whole plant with haptera at the base (stained with saffranin); inset shows a part of the dichotomy enlarged to show a midrib. B. A cross section of the axis showing thickened central region of conducting tissue and flanges on both the sides. C. Midrib portion partly enlarged showing details of conducting tissue (ct), cortex (c) and epidermis (ed). D. A portion of the flange enlarged. E. A peeled off epidermis in surface view. Bars: $A=2 \mathrm{~cm}, \mathrm{~B}=300 \mu \mathrm{m}, \mathrm{C}-\mathrm{E}=60 \mu \mathrm{m}$

Discussion: Islam (1976) reported G. tenuissima Feldm. et Hamel from the St Martin's Island, attached to shells and corals or entangled with other algae.

Habitat and local distribution: Plant was attached to soft substratum, along with other algae in the intertidal pools on the west coast of St. Martin's Island; collection no. 254, 06 Jan. 1986; common. 


\section{Order: Cryptonemiales, Family: Grateloupiaceae}

3. Halymenia floridana J. Ag.

(Figs 3 A-D)

(Taylor 1960, 420, Pl. 53, Fig. 2)

Synonym: Halymenia bermudensis F. S. Collin \& M. A. Howe H. gelinaria F. S. Collin \& M. A. Howe

Habit: Plants of moderate to considerable size, foliaceous, generally of a gelatinous consistency.
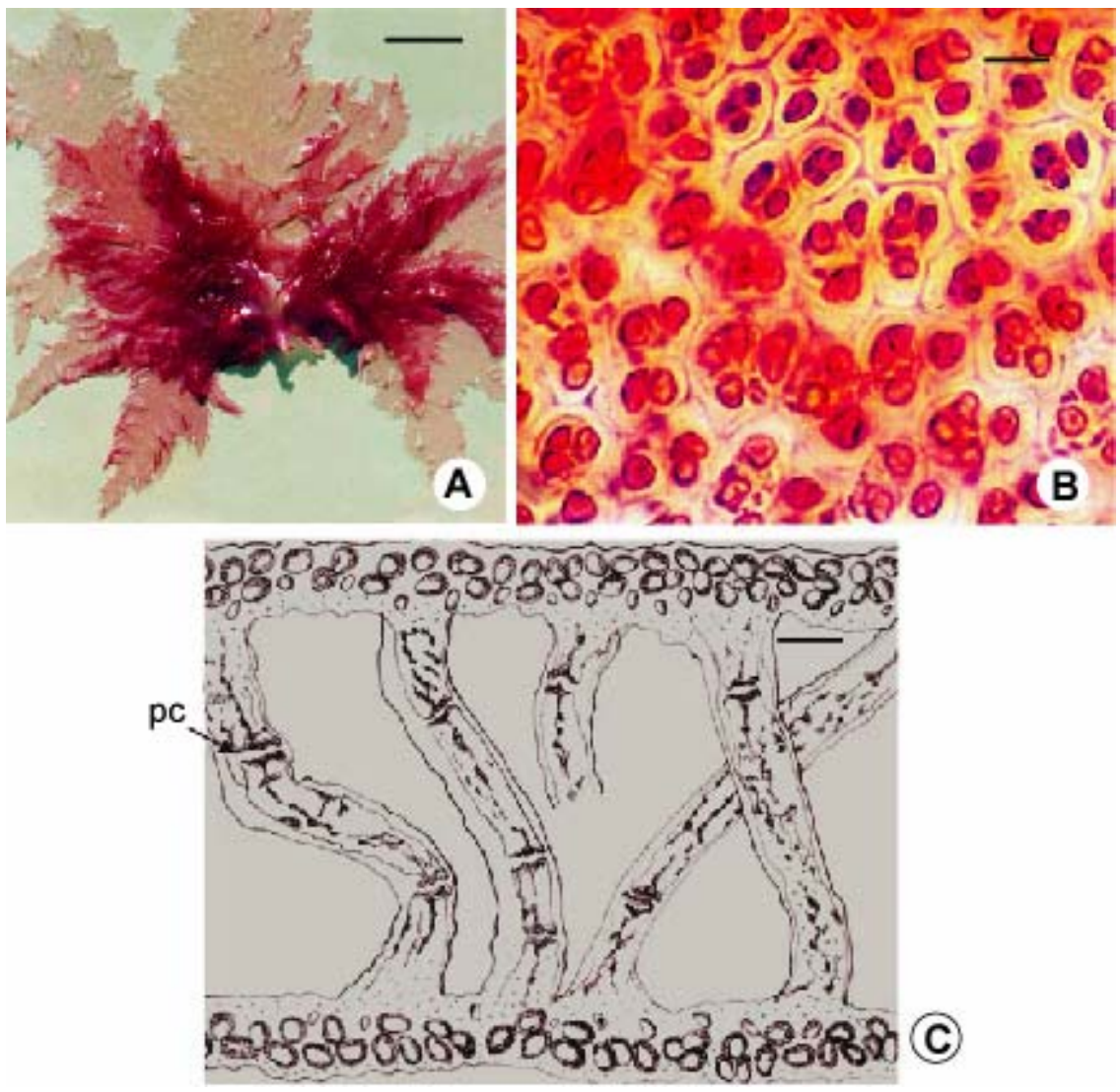

Figs 3 A-C. Halymenia floridana: A. A living plant spread apart. B. Surface view of the thallus showing epidermal cells which appeared to be grouped in a layer within the common parent wall. C. A camera lucida drawing of tranverse section of the thallus showing epidermis, narrow cortex and wide medulla with prominent hyphae (pc = pit connections). (A. Natural colour; B. Stained with saffranin). Bars : A = 1.2 $\mathrm{cm}, \mathrm{B}-\mathrm{C}=20 \mu \mathrm{m}$.

Vegetative structure: Plants foliaceous, incised, texture membranaceous with gelatinous consistency, rose or purplish; blades 5 - $10 \mathrm{~cm}$ tall, 4 - $10 \mathrm{~cm}$ wide, borne on a slender very short (few millimeters long) stipe; at first ovate and entire, but later forming numerous lobes, which are cuneate below and taper toward the apices, finally becoming laciniate, somewhat palmatifid; blades $152 \mu \mathrm{m}$ thick. Epidermis appeared single layered, vertically divided producing a group of epidermal cells usually of fairly uniform diameter $(10.16-15.24 \mu \mathrm{m})$ surrounded by common parent cell; cortex narrow, 1 - 2 celled thick; medulla wide, traversed by many irregularly 
branched hyphae of various sizes, 48.1 - $50.8 \mu \mathrm{m}$ long, 8.89 - $11.25 \mu \mathrm{m}$ broad, frequently anastomosing and almost at right angle to the thallus surface. Surface jelly of the thallus conspicuous, easily dispersed from dried specimens. Cystocarps and tetraspores not found.

Discussion: So far $H$. duchassaigne, $H$. floresia, $H$. dilata and $H$. maculata have been reported from the St Martin's Island. (Aziz et al. 2002, Islam and Aziz 1987).

Habitat and local distribution: The plant was collected as a drifted form from the west coast of St. Martin's Island, during low tide; collection no. 258, 01 March, 1995; common.

\section{Order: Ceramiales, Family: Rhodomelaceae Genus: Falkenbergia Schmitz}

\section{Falkenbergia hillebrandii (Bornet) Falkenberg}

(Figs 4 A-E)

(Taylor 1960, 571-572, Pl. 72, Fig. 8)

Synonym: Asparagopsis taxiformis (Delile) Trevisande Saint-Leon

Habit: Plants small, soft, filamentous and profusely branched.
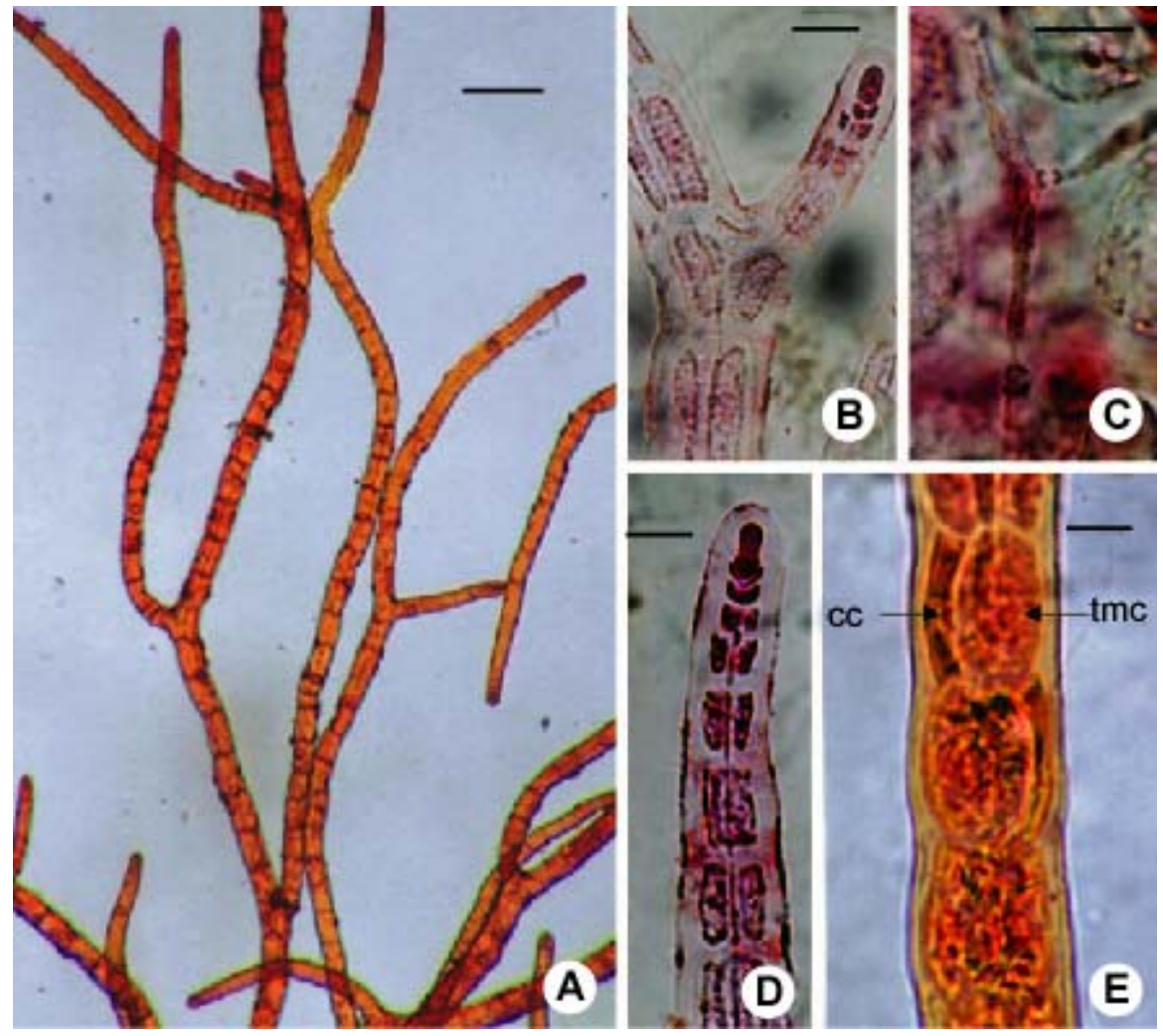

Figs 4 A-F. Falkenbergia hillebrandii (Bornet) Falkenberg: A. A portion of the upper part of a plant showing branching pattern. B. Branch development from the middle of a segment of the plant. C. The branched portion of fig. B enlarged showing the axial cell and its branching from its middle; note also the pit connection at the middle of the axial cell. D. Terminal part of the filament showing the typical apical cell. E. A branch showing tetrasporangial mother cell (tmc) and a cover cell (cc). Bars: A = $100 \mu \mathrm{m}, \mathrm{B}, \mathrm{D}-$ $\mathrm{E}=10 \mu \mathrm{m}, \mathrm{C}=5 \mu \mathrm{m}$. 
Vegetative structure: Plants more than $2 \mathrm{~cm}$ long, no rhizoidal structures are found along the whole length of the filament. Branching irregular develop almost at right angle from the middle of a segment (Fig. 4A-B), an axial cell also produce branch from its middle (Fig. 4C). Pericentral cells large, 3 in number around a very narrow $(2.00 \mu \mathrm{m})$ axial cell. Pericentral cells up to a maximum of $25.4 \mu \mathrm{m}$ broad and $76.2 \mu \mathrm{m}$ long. Main axis up to $33.0 \mu \mathrm{m}$ broad. Apical cells large, dumbell shaped up to $15.24 \mu \mathrm{m}$ long and $7.62 \mu \mathrm{m}$ broad.

Reproductive structure: Distinct reproductive structures were not found. In rare cases distal part of ultimate branches was found to produce tetraspore mother- cell like structure where one of the three pericentral cell narrowed to produce cover cell of the tetrasporangia (Fig. 4E).

Discussion: As per description of the genus the holdfast develops at the very base of a thallus but in the present materials multicellular branched holdfast was not found even in the proximal part of $2 \mathrm{~cm}$ long thallus.

Habitat and local distribution: The alga grows on Liagora harveyiana Zeh; which was found to be growing on boulders; collection no. 255, 01 March, 1995; common.

\section{Polysiphonia harveyi Bailey}

\section{Genus: Polysiphonia Greville}

(Taylor 1957, 332, Pl. 56, Fig. 8)

Habit: Plants erect, usually laterally branched.

Vegetative structure: Plants branched, $3.44 \mathrm{~mm}$ tall, basally attached by rhizoids developed from underside of creeping axis; texture soft to rather stiff, slender, color pinkish when young, later light-brown to blackish; irregularly and laterally branched, usually once from upper part of the axis; erect main axes up to $3.45 \mathrm{~mm}$ long and 46.5 - $62.7 \mu \mathrm{m}$ broad, prostate creeping part 67.2 - $113.7 \mu \mathrm{m}$ broad. Length of basal segments up to $93.1 \mu \mathrm{m}$ and $51.1 \mu \mathrm{m}$ broad. Near the tip, segments $25.9 \mu \mathrm{m}$ long and $62.0 \mu \mathrm{m}$ broad, with 4 pericentral cells, up to $36.19 \mu \mathrm{m}$ broad. Pericentral cells of prostate part up to $93.1 \mu \mathrm{m}$ long and $23.27 \mu \mathrm{m}$ broad. Rhizoids unicellular developed from the base of a pericentral cell, while polysiphonous branches develop from the upper part of a tire of pericentral cells. Trichoblasts numerous at the distal end, dichotomously branched consisting of long narrow cells, almost colorless appearing as hairs, up to $414 \mu \mathrm{m}$ long.

Reproductive structure: Spermatangial branches cylindrical mostly developed on the tip of a basal cell of a trichoblast, up to $170.6 \mu \mathrm{m}$ long and $56.9 \mu \mathrm{m}$ broad at the base while $49.1 \mu \mathrm{m}$ broad near the tip. Young developing spermatangial branches are lanceolate in shape. Cystocarp broadly ovoid, $196.5 \mu \mathrm{m}$ long and $134.4 \mu \mathrm{m}$ broad. Carpogonium develops from a segment situated near the base of a branch; trichogyne short, cylindrical (Fig. 5E), $38.78 \mu \mathrm{m}$ long, $3.10 \mu \mathrm{m}$ broad. Carpospores fusiform, broader end rounded, $51.7 \mu \mathrm{m}$ long and $15.51-18.10 \mu \mathrm{m}$ broad at the rounded end.

Discussion: Islam (1976) reported P. denudata (Dill.) Kütz. and $P$. mollis Kooh et Harv. from the St Martin's Island. The later species was found to be growing epiphytically on Liagora sp., like the present species.

Habitat and local distribution: Plants were collected from the base of Liagora harveyiana Zeh which was found on the west coast of St Martin’s Island; collection no. 252, 06 Jan. 1986; common. 

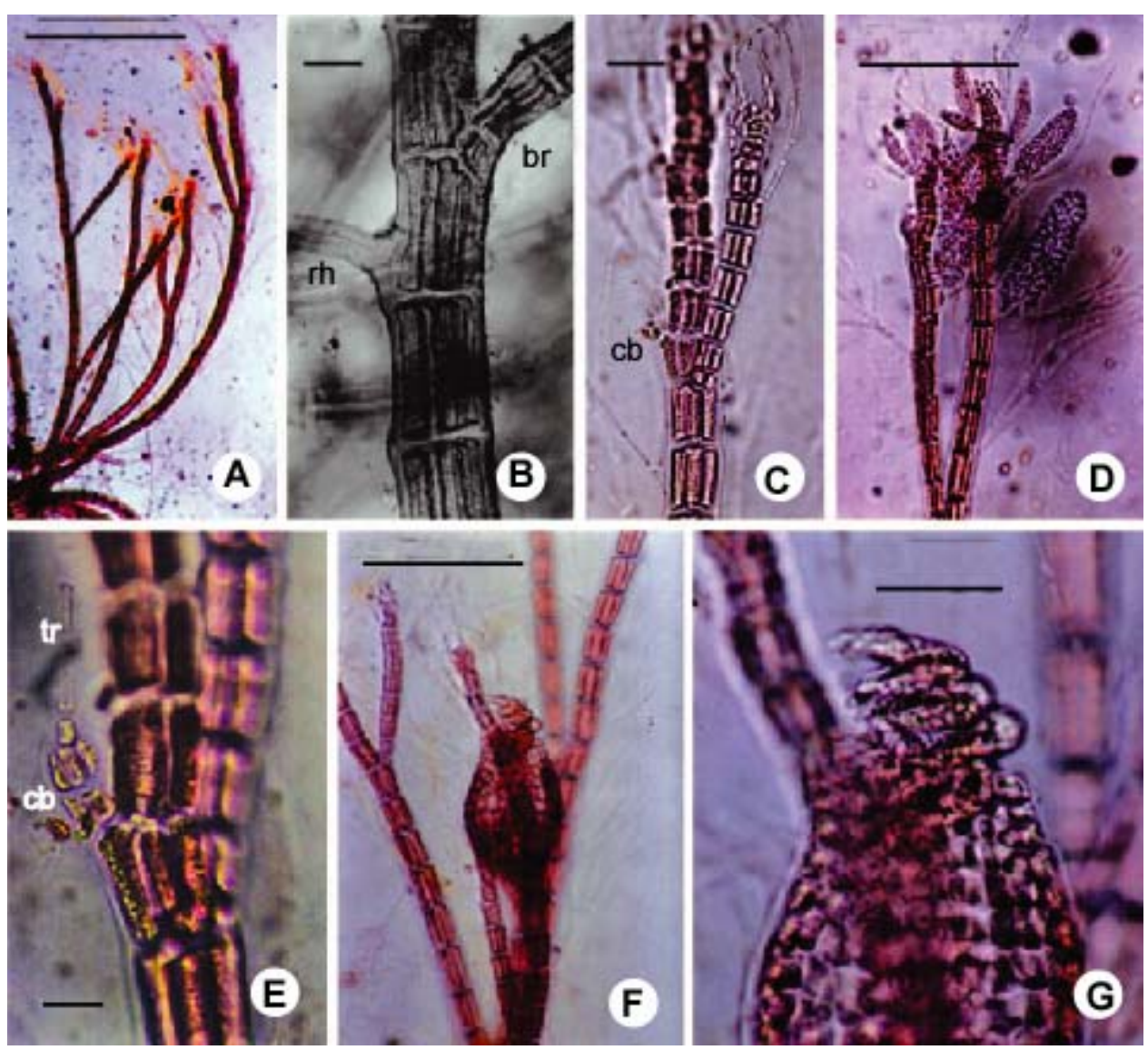

Figs 5A-G. Polysiphonia harveyi: A. An aggregate of thalli showing habit of plants. B. A part of creeping axis with a rhizoid (rh) and a branch (br)on the right. C. Distal end of an axis with trichoblasts, note the carpogonial branch (cb) near the dichotomy. D. Distal end of the plant with spermatangial clusters of various ages. E. An axis with carpogonial branch (cb) developed from the upper side of a segment with short trichogyne (tr). F. A cystocarp near the axil of a branch. G. Carpospores oozing out of the cystocarp. Bars: $A=1 \mathrm{~mm}, \mathrm{~B}, \mathrm{G}=50 \mu \mathrm{m}, \mathrm{C}=25 \mu \mathrm{m}, \mathrm{D}, \mathrm{F}=200 \mu \mathrm{m}$.

\section{References}

Ahmed ZU, ZNT Begum, MA Hassan, M Khondker, SMH Kabir, M Ahmad, ATA Ahmed, AKA Rahman and EU Haque (Eds) 2008. Encyclopedia of Flora and Fauna of Bangladesh. Vol. 3. Algae, Chlorophyta (Aphanochaetaceae-Zygnemataceae). Asiat. Soc. Bangladesh, Dhaka. 812 pp.

Ahmed ZU, M Khondker, ZNT Begum, MA Hassan, SMH Kabir, M Ahmad, ATA Ahmed and AKA Rahman (Eds) 2009. Encyclopedia of Flora and Fauna of Bangladesh. Vol. 4. Algae, CharophytaRhodophyta (Achnanthaceae-Vaucheriaceae). Asiat. Soc. Bangladesh, Dhaka. 543 pp.

Aziz A and Shahima Islam 2009. Marine algae of St. Martin's Island, Bangladesh. VII. Acrochaetium nurulislamii sp. nov. and new records of Acrochaetium. Bangladesh J. Bot. 38(2): 145-151.

Aziz A, Shahima Islam and AH Chowdhury 2010. Marine algae of St. Martin’s Island, Bangladesh. X. Green algae (Chlorophyceae). Bangladesh J. Plant Taxon. 17(2): 193-198. 
Aziz A, AKM Nurul Islam and A Jahan 2002. Marine algae of St. Martin’s Island, Bangladesh. III. Red algae. J. Asiat. Soc. Bangladesh (Sci.) 28(1): 63-70.

Islam AKMN and A Aziz 1987. Addition to the list of the marine algae of St. Martin's Island, Bangladesh. III. Red algae. Nova Hedwigia 45: 211-221.

Islam Shahima, A Aziz and AH Chowdhury 2010. Marine algae of St. Martin’s Island, Bangladesh. IX. Red algae (Rhodophyceae). Bangladesh J. Bot. 39(1): 87-96.

Islam AKMN 1976. Contribution to the study of the marine algae of Bangladesh. Bibliotheca Phycologica 19: 1-253.

Nora R De Rios 1972. Contribucion Al Estudio Sistematico De Las Algas Macroscopicas De Las Costas De Venezuela. Acta Botánica Venezuellica 7: 1-277.

Taylor RW 1957. Marine algae of the northeastern coast of North America. Univ. Mich. Press, Ann Abor. 509 pp.

Taylor RW 1960. Marine algae of the eastern tropical \& subtropical coasts of the America. Univ. Mich. Press, Ann Abor. 870 pp.

Womersley HBS 1965. The Helminthocladiaceae (Rhodophyta) of Southern Australia. Aust. J. Bot. 13: 451$87+7$ plates.

(Manuscript received on 12 August, 2010; revised on 23 November, 2010) 